\title{
The Extent to Which Servant-Leadership Philosophy Relates to Public Leadership Code of Ethics and Other Established Ideals for Public Leaders in Tanzania
}

\author{
Saneslaus Boniface Chandaruba \\ Department of Political Science and Public Administration, The Open University of Tanzania (OUT), Dar es Salaam, Tanzania
}

Email address:

bonnychandaruba74@gmail.com

\section{To cite this article:}

Saneslaus Boniface Chandaruba. The Extent to Which Servant-Leadership Philosophy Relates to Public Leadership Code of Ethics and Other Established Ideals for Public Leaders in Tanzania. Journal of Public Policy and Administration. Vol. 3, No. 1, 2019, pp. 8-18.

doi: 10.11648/j.jppa.20190301.12

Received: January 29, 2019; Accepted: March 14, 2019; Published: April 10, 2019

\begin{abstract}
The main objective of this research paper was to examine the extent to which Servant Leadership Philosophy (SLP) relates to the Public Leadership Code of Ethics Act (PLCEA) of 1995 and other established ideals for public leaders in Tanzania. A total of 278 respondents: 109 Members of the Parliament (MPs), 90 Respondents from General Public (RGPs) and 79 key informants selected from different constituencies and localities across the country using a non-probability approach of snowball sampling were involved. Both qualitative and quantitative methods of data collection and analysis were employed. The primary and secondary data were collected through questionnaires, interviews, observations and documentary review. The key research findings revealed that that SLP relates a little bit to PLCEA and other established ideals for public leaders in Tanzania for they both have ethical characteristics intending to set controls over public leaders. A number of difference were established during the study to justify why they were a little bit related. The major difference based on the premises that the philosophy of servant leadership seems to embody socialistic and spiritual characteristics with a major focus on elevating followers to the same status of the leader while PLCEA and other established ideals are mainly based on a legal compliance approach. The other established differences basically focused on personal qualities of a leader in each category. Thus, the study recommends, among other things, enhancing PLCEA and other established ideals for public leaders by adopting the principles of SLP; training public leaders on SLP and including SLP in school curricula topics with a view of grooming patriotic and ethical leaders of the next generation.
\end{abstract}

Keywords: Servant-leadership, Public Leadership, Tanzania, Political Leadership

\section{Introduction}

Public leadership, as a discipline, has been over the years, receiving more intellectual attention accross the world associated with a mushrooming of contemporary theories and models to explain its nature, essence and the way it has been evolving to meet the ever-changing needs of the human being. The classical struggle for designing the state emerged during the enlightenment age in the 17th Century in Europe is said to have an important contribution on defining public leadership and the role of the state. Northouse [1] contends that Locke being one of the great philosophers during the enlightenment age, made a major contribution through his most famous work of the Two Treatises on Goverment. The work was published in 1689 and it essentially helped to define the role of the state to its people emphasizing that the government through its public leaders (acumen) has moral obligations and responsibilities of protecting the natural rights of the people they govern in terms of life, liberty and their properties. Locke further argued that the best government is that being accepted by its people and that which has limited powers, giving an example of the English monarchy where laws limited the power of the King. It is widely believed that Locke's ideas influenced Thomas Jefferson more than anything else in writing the US Declaration of Independence in 1776, and later on towards revolutions made in France of 1789 and many other places in the world in the $19^{\text {th }}$ Century. 
It is important to note that quality public leadership in a society is an exclusive factor for it acts as a driving force of all other available development trajectories. But also it is important to admit that having quality leadership in our societies today is a major challenge. For it is a complex leadership process which takes a long way with a need of change of attitude of people backed with patriotism spirit, dynamic leadership framework, proper code of ethics and other established ideals for public leaders in that particular society. That is why SLP has become one of the leadership theories that have drawn a flurry of interest in trying to explain how quality public leadership can be enhanced in a society. But also on explaining how public leadership flaws such as corruption, conflict of interests, embezzlement, unilateral decision making and all other malpraticed evils can be curbed. The servant leadership philosophy is also claimed to help public leaders by inculcating in their thoughts new dimensions of thinking on serving their societies better rather than looking at their personal interests $[2,3]$; for the common good of the community is more important than individual interests [4].

Tanzania has its own code of ethics and other established ideals to control its public leaders. However, despite the efforts made by the Tanzania government through the enactment of PLCEA in 1995 and establishment of many other ideals to bind public leaders, there is a considerable number of leadership deficiencies still reported from the Tanzania public service especially from the political realm. Most political leaders particularly MPs instead of being servant-leaders of their electorates are accused of being unethical, corrupt and selfish abusing their entrusted powers for personal interests contrary to the code of ethics. They are also blamed for lacking moral obligations and alleged to betray their voters by giving them good promises during campaigns while doing nothing once elected and sometimes rarely seen in their constituencies [5]; for they really know that voters have no power to impeach them until the following election. Gasarasi [6] insists that although MPs have a major constitutional function of overseing the government in order to safeguard public interests, in reality this seems not likely to be the most priority to most of them. Also, as revealed by Liviga [7] most people in Tanzania contest for MPs seats not because they are committed and have inner feelings of serving their communities but it is because they want financial gains and other personal emoluments associated to the position.

Voters, in that view, complain against their MPs' integrity, performance and accountability pointing fingers to the Constitution of the United Republic of Tanzania of 1977 and PLCEA for not giving them a direct mandate of holding their MPs responsible once they go wrong. As a result, there is a considerable outcry of electorates from various constituencies across the country who are endlessly raising their voices against their MPs for betraying them and abusing their entrusted powers which should not be ignored. Although this problem of public leadership is at the extreme and it is extensively discussed, no study so far has established the extent to which SLP relates to PLCEA and other established ideals for public leaders in Tanzania. This study therefore apart from assessing the prospects and challenges of adopting SLP, it also aimed at bridging this gap by examining the extent to which the fundamental principles of SLP relates to PLCEA and other established ideals for public leaders in Tanzania especially MPs with a view of assessing their comparative advantages.

\section{Literature Review}

The Public Leadership Code of Ethics Act No. 13 of 1995 is the principal legislation established by the Parliament of the United Republic of Tanzania to provide ethical standards to be adhered to by all public leaders. The Act also provides guidelines for ethical decision making processes by public leaders to ensure effective use of political authority, exercise of control over society and management of country's resources for sustainable economic development, and improvement of the quality of life and social well-being [8]. Adamson [9] contends that a strong government should have strong code of conduct and moral obligations to restrain its public leaders from abusing their powers for personal interests, otherwise, that government and its leaders may lose legacy and public confidence.

This study adopted the definition of code of ethics as provided in the Public Leadership Code of Ethics Act No. 13 of 1995. The established ideals simply means a set of acts, principles, rules and regulations that guide a leader in addition to PLCEA. In the context of this study, a set of established ideals includes; the Parliamentary Immunities, Powers and Privileges Act of 1988, the National Assembly Administration Act of 2008; the Parliamentary Standing Orders, Rules and Regulations and the National Integrity Pledge for Public Leaders of 2015. Generally, PLCEA and the other established ideals are aimed at providing MPs with guidelines in the due process of discharging their duties and responsibilities. They also aim at enhancing the integrity and credibility of MPs and other public leaders in the eyes of their voters and the public at large and therefore to underpin the public confidence and trust in the Parliament and the state as a whole.

\subsection{The General Leadership Theory}

The general theory of leadership significantly justifies about different fundamental scholars' views on how an individual can emerge a leader. Scholars tend to hold two contending views about leadership. One school of thought holds that leaders are born $[10,11]$ and that the qualities they embody are subconscious while the other school of thought contends that people need to work hard to develop these qualities before they can emerge as leaders [12, 1]. Therefore, the general leadership theory as contended by Bass and Stogdill [13] underlines three fundamental ways to explain how people become leaders. The first two ways explain leadership development for a small number of people that; some personality traits may lead people naturally into 
leadership roles - this is the Trait Theory; and that, a crisis or an important event may cause a person to rise to the occasion which brings out extraordinary leadership qualities in an ordinary person - this is the Great Events Theory. The third way assumes that some people choose to become leaders and therefore they can learn leadership skills. Basing on the third approach, it is generally held that it is possible for an individual who choose to become a leader to learn and become a good leader.

The general theory of leadership was found to be relevant to this study because of its importance on explaining about how an individual emerges as a leader. However, the theory assumes that all leaders aim at helping their organizations to effect changes. This is not always true in the contemporary world for some leaders especially from the political realm as contended by Liviga [7] and Gasarasi [6] seek to become leaders for their personal interests. Therefore, despite the significant contribution it has made to this study, there is a need of searching for more theories and approaches that explain on why some individuals become leaders as means of addressing the existing public leadership deficiencies in the context of Tanzania especially in the political realm.

\subsection{Servant Leadership Theory}

The term servant is defined as "one who is under obligation to work for the benefit of a superior and to obey his or her commands" [14]. Thus, according to Sendjaya and Cooper [15], a servant leader is a person who has an innate desire to serve and strives to meet the highest priorities of others. The original term servant leader is often accredited to Christianity and the biblical teachings of Jesus where $\mathrm{He}$ gives instruction on the qualities of a leader, the role of the leader and the issue of power or authority of a leader [16]. The term philosophy is defined as "a system in which the ontology, epistemology and axiology informs and impacts ones view of the world" [17]. Servant leadership philosophy therefore is concerned with the entire system in which a leader engages with a follower through the desire and process of serving in such a way that the leader and follower raise one another to a higher level of morality and motivation.

The theory of servant leadership was derived from analogical or interpretive reasoning in which Greenleaf essentially used a metaphorical character (identified as a servant leader) and demonstrated leadership aligning with his own values, beliefs, and knowledge $[18,19]$. The theory is a two-fold concern of which Greenleaf [20] brings about two fundamental assumptions. The first assumption is that individuals who want to tackle problems of the world do so intellectually; and the second one is that individuals who want to serve often miss the opportunity. According to Greenleaf [20], there are many problems in the world that need to be tackled by intellectuals but unfortunately only a few of them get the opportunity to do so, the rest miss that opportunity because of limited chances. The theory therefore assumes that few number of individuals emerge as leaders not because they want to benefit themselves but it is because they have the desire to serve others and they do so on behalf of those who missed the opportunity. Spears [21] expanded the work of Greenleaf by exploring four central tenets which, if taken separately, they basically present a fuller picture of the Servant-leadership framework pin-pointing the fundamental principles of the theory itself. The four tenets can be identified and expounded as;

\subsubsection{Increased Service to Others}

The central idea of this tenet stands on a strand that servant-leadership begins when a leader assumes the role of a servant to others interacting with followers. It is held that a servant-leader's primary motive is to serve others with quality services encouraging greatness in them. The legitimacy of a servant leader arises not from the exercise of his power or self-interested actions, but it is from his fundamental desire to first help others. According to Greenleaf [20] the desire to serve others first is the fundamental simple fact and the central key to a leader's greatness.

\subsubsection{Holistic Approach to Work}

The servant leadership philosophy holds that the work exists for the person as much as the person exists for the work [20]. The theory poses challenges on institutions to rethink about relationships that exist amongst people themselves, their institutions and a society as a whole. The theory therefore promotes a view that individuals should be encouraged to be who they are in their professionals as well as personal lives and consequently to have holistic approach in doing their common interest works. Greenleaf [20] therefore contends that this integrated valuation of individuals ultimately benefits the long-term interests and performance of the society as a whole.

\subsubsection{Promoting a Sense of Community}

The servant-leadership theory questions on institution's ability, in this case the government, to provide the community with good social services. The theory argues that only a community, which is defined as groups of individuals that are jointly liable for each other both individually and as a unit, can perform this function [22]. The theory also emphasizes that it is only by establishing this sense of community among followers can an organization or a community succeed in its objectives. However, Greenleaf [20] further contends that the sense of community can arise only from the actions of individuals who are servant leaders.

\subsubsection{Sharing of Power in Decision-making}

This tenet emphasizes that followers are not mere sheep; for they have ability to think and weigh things before making their own decisions. Thus, an effective servant leader is supposed to involve them in deciding the aftermath of their common interests. By so doing, a servant leader is said to cultivate in his followers the spirit of servant-leadership by nurturing participatory and empowering them, and encouraging their talents. In that case, the servant-leader creates a more effective, motivated workforce and ultimately a more successful organization or society. As pointed out by 
Cooper [23] servant leaders enable others to act not by hoarding the power they have but by giving it away.

Generally, servant leadership has become a theory for moral and ethical leadership that focuses on follower's development, community building, authentic leadership, and shared leadership [24, 15]. That is why Spears [25] and McGee-Cooper and Trammell [3] see it as a new kind of leadership theory which opens a new ground of emphasis in a leadership discipline.

\subsection{Empirical Literature Review}

The spirit of servant leadership philosophy had been traditionally practiced in Tanzania for centuries before colonialism. Even after its independence Tanzania impliedly inherited some of the SLP practices in its formal government operations. For example, the government through the then ruling party of Tanganyika African National Union (TANU) formulated the so-called ten (10) pledges of TANU which were issued in 1962 as guiding principles of commitment. Indeed, these pledges had equal weight to the fundamental principles of SLP. Nyerere [26] contends that the major aim of these TANU pledges was to propagate self-dedication of public leaders to serving the public instead of oneself or personal interests. This is evidenced from pledge No.4 which identifies corruption as a society enemy while pledge No.5 prohibits the use of official position or that of any other person for personal gain. Likewise, in 1967 the government proclaimed the Arusha Declaration which essentially laid down the national policy of socialism and self-reliance Ujamaa na Kujitegemea. Through the Arusha Declaration the government nationalized all the means of production and put them under the government control. In tandem with nationalization of all means of production from private owners, also the government explicitly stated for the first time after independence the qualifications of public leaders. Since then, good leadership was formally recognized as one of the four pillars of the national development; others were land, people and good policies.

The Ujamaa philosophy, just like Harambee in Kenya or Ubuntu in South Africa, embodies some characteristics relevant to those of SLP. This is because its focus and fundamental principles aim at enhancing quality social services to the public, promoting a sense of community and encouraging devotedness and patriotism in the society which are some of the characteristics found in SLP.

However, despite the fore-mentioned initiatives, some empirical studies made in Tanzania [27-31] have indicated that, Tanzania, like other third world countries is still facing a lot of challenges in the area of public leadership especially after the introduction of multiparty system in early 1990 s. Thus, in 1995 the government enacted PLCEA with the aim of instituting and invoking fundamental principles in respect of the conduct of public leaders. The Act stipulates on how public leaders should act while in office including an obligation of declaring all properties or assets and liabilities they have. It also stipulates very clearly the way leaders are supposed to restrain their personal interests from that of the public being enshrined under Section 6 (e) of the Act as following;

"In relation to public interest, that on appointment or election to office, and thereafter, public leaders shall so arrange their affairs as will prevent real, potential or apparent conflicts of interest from arising, but if such a conflict does arise between the private interests of a public leader and his official duties and responsibilities, the conflict shall be resolved in favour of the public interest"' [8].

Despite the enactment of PLCEA, Tenga [32] contends that the problem has not been curbed yet. That is, the conflict of interest and conduct of public leaders are not sufficiently checked and restrained from their personal interests. It is reported on the Citizen Newspapaer [33] that public leaders have lost patriotism and commitment of serving others, some even abandoning their professions looking for more money. That is why we see professors eagerly quitting teaching to join politics because they absolutely know that there is green pasture. That means, what forces them to join in politics is not the inner feeling or commitment of serving others first; it is a self-centred interest of enriching themslves. This has become one of the major setbacks to be dealt with if really Tanzania needs to promote quality leadership and socioeconomic development.

Ngowi [34] contends that the problem of leadership particularly in politics should not be ignored and let to persist for there is a strong relationship between the political leadership factor and economic development of a society. Likewise, the former President of the United Republic of Tanzania Jakaya Mrisho Kikwete when launching a programme on Leadership and Ethics Studies at the Mwalimu Nyerere Memorial College at Kigamboni, Dar es Salaam, he also admitted that there is a leadership problem (dubbed it as leadership vacuum) and it is not yet curbed. He principally concurred with Ngowi's arguement about the importance of political leadership on achieving development in a society emphasizing that "... true development will come from ourselves as a nation but it is so more important with good politics and clean leadership" [35]. Kikwete also argued the College to offer programmes that aim at grooming leaders in Tanzania through good succession plan and mentorship in order to create a good foundation for future leadership and governance.

According to Nassor [36] a leadership forum conducted by the Tanzania Public Service College (TPSC) during the development of the Leadership Competency Framework (LCF) identified and prioritized some public service challenges, which shape the required competencies for leaders in Tanzania. The LCF was developed based on the systems approach to provide right answers to these key questions: what skills, knowledge and attributes do public service leaders in Tanzania need? What is the critical set of leadership competencies required that will address the challenges of the 21 st century public service and drive reforms? During the survey a sample of 229 respondents were obtained including permanent secretaries from different ministries and other public servants and got interviewed. 
The findings of the survey revealed a high degree of consensus around key organizational factors impacting leadership capacity along with possible implications for developing a leadership framework. As listed by Nassor [36] the key organizational factors identified were: (i) The need for succession planning as a sizeable population of senior managers were due for retirement in the next three years; (ii) The need to promote strategic thinking to drive reforms and change in the public service; (iii) Adoption of new public management as against maintaining status quo bureaucracy; (iv) Need to adopt results and outcomes based management; (v) Capacity constraints that led to fear of delegating; (vi) Alignment to political agenda for political support; (vii) Accountability enhancement; (viii) Need for an human resources development strategy; and, (ix) Low impact, supply driven training interventions. The Survey also produced a list of top ranked leadership attributes among all Tanzania public service leaders. These competencies were taken to be the foundation of any leadership assessment and development effort in the Tanzania public service. The attributes were: building integrity and trust; providing and accepting constructive feedback; delegating responsibilities effectively; clarifying roles and expectations; setting performance standards; ensuring policy adherence; ensuring accountability for results; and recognizing work of others.

Although the leadership survey was appreciated for lying down a good foundation for resolving public leadership deficiencies in the Tanzania public service, it still faces some empirical criticisms on two major grounds; (i) it doesn't answer the question of which appropriate leadership approach fits in the public leadership framework, and therefore it ignores the problem of restraining public leaders' individual interests from that of the public and other existing leadership deficiencies (ii) it also lacks reliability for it eventually produces a list of top ranked leadership attributes amongst all Tanzania public leaders while the used sample of 229 respondents did not include any political leader who are also recognized as public leaders under PLCEA of 1995.

It is generally observed that, in Tanzania, unlike in other countries where scholars and researchers have put more emphasis on the role of servant leadership philosophy in their societies, there is no adequate empirical literature of local researchers and scholars available patterning to the philosophy per se. This implies that no enough efforts have been dedicated to espousing this approach amongst leaders; in that case, the philosophy is found to be a new ground to public leadership development in Tanzania which needs to be espoused.

\section{Methodology}

A case study design was employed and it involved both qualitative and quantitative approaches. The two approaches were integrated in this study basing on the views of Kothari [37] and Bryman [38] who suggest that it is essential to integrate the two approaches in order to enhance validity and reability of the reseaserch findings. During the study a sequential strategy was used as recommended by Creswell [39] where a qualitative approach was used first through text analysis, questionnaires and semi-structured interviews to explore data on the phenomenon. Then, the quantitative approach followed for analyzing the generated data. The population involved in this study consists of MPs from the Parliament of the United Republic of Tanzania, key informants from a number of institutions whose roles and functions are much related to the study and respondents from the general public.

The study had an estimated sample of 300 respondents supposed to be drawn from three categories; 120 MPs from the Parliament of the United Republic of Tanzania, 90 key informants from selected institutions whose functions and roles bear an essential contribution to the study including; Officials from the Parliament office, Ex-MPs, Registrar of political parties and leaders from political parties, respondents from academic institutions, the Judiciary of Tanzania and Commission for Human Rights and Good Governance (CHRAGG). Others include religious leaders, Tanzania Gender Networking Programme (TGNP), TWAWEZA and Research for Poverty Alleviation (REPOA). The third category comprised of 90 respondents from the general public.

The instruments for both primary and secondary data collection were employed. The primary data from MPs and RGPs were collected through questionnaires while the data from key informants were collected through semi-structured interviews. The primary data, in this case, were found to be more useful and consistent to the research problem on the ground that they were collected for a specific problem at hand. On the other hand, the secondary data were collected from various sources such as parliamentary hansards, reports and publications; different speeches and parliamentary website; other sources were libraries, text books, journals and newspapers. To simplify the data analysis process, the collection of data were made according to the three categories of respondents; MPs, RGPs and key informants.

\section{Results}

Out of the estimated sample size of $300(100 \%)$ respondents, $278(92.67 \%)$ of them responded during the study; the rest $22(7.33 \%)$ had various reasons to justify their absence. This response rate is found to be appropriate as argued by Sekaran [40] that any response rate above $75 \%$ is classified as best response rate and is believed to provide reliable information. But also, this response rate is higher compared to those of the previous studies made by other scholars such as Awino [41] who had a response rate of $57 \%$ and Abok et. al [42] whose response rate was 55\% respectively from the target population of their studies. Mugenda and Mugenda [43] also contend that, in conducting a study, any response rate at the extent of $50 \%$ is said to be sufficient, $60 \%$ is good and $70 \%$ and above is excellent. Therefore, it is clearly believed that the response rate of this study is excellent and hence provides reliable information. 


\subsection{MPs' Views}

On establishing the extent to which SLP relates to PLCEA and other established ideals for public leaders, MPs were requested to give their views by making comparison between the given variables using the given four likert-scaled options of 'closely related', 'a little bit related', 'not related at at all' and 'I don't know'. Each respondent, in that case, was asked to select only one option out of the four given options to express his or her feelings. Table 1 shows the rating of responses of all $109(100 \%)$ MPs who participated in the study.

Table 1. MPs'views on the extent to which SLP relates to PLCEA and other established ideals.

\begin{tabular}{|c|c|c|c|c|c|}
\hline \multirow{3}{*}{ Question: } & \multicolumn{5}{|c|}{ No. of Respondents involved $(\mathrm{N}=109)$} \\
\hline & \multicolumn{5}{|c|}{ Responses Rating } \\
\hline & $\begin{array}{l}\text { Closely } \\
\text { Related }\end{array}$ & $\begin{array}{l}\text { A Little Bit } \\
\text { Related }\end{array}$ & $\begin{array}{l}\text { Not Related } \\
\text { at All }\end{array}$ & $\begin{array}{l}\text { I Don't } \\
\text { Know }\end{array}$ & Total (\%) \\
\hline $\begin{array}{l}\text { To what extent do you think the principles of servant leadership philosophy } \\
\text { of: increased service to others; holistic approach to work; promoting a sense } \\
\text { of community; and sharing of power in decision-making process relate to } \\
\text { PLCEA and other established ideals for public leaders in Tanzania? }\end{array}$ & $13(11.93 \%)$ & $59(54.13 \%)$ & $17(15.60 \%)$ & $20(18.34 \%)$ & $109(100 \%)$ \\
\hline
\end{tabular}

Source: Research Data, 2015

Basing on the data provided in Table 1, the research findings revealed that $59(54.13 \%)$ MPs out of $109(100 \%)$ participated in the study were of the views that servant leadership philosophy was 'a little bit related' to PLCEA and other established ideals for public leaders in Tanzania. There was only a sub-cluster consisting of 13(11.93\%) MPs whose views suggested that servant leadership philosophy was 'closely related' to PLCEA and other established ideals for public leaders in Tanzania. The rest respondents they either suggested 'not related at all' or declared to know nothing about the existing relationship between servant leadership philosophy and PLCEA and other established ideals.

The detailed analysis made in Figure 1 reveals that 59(54.13\%) MPs which is more than a half of the respondents from the MPs' category had the opinions that servant leadership philosophy is 'a little bit related' to PLCEA and other established ideals for public leaders in Tanzania. It also reveals that there was a significant number of MPs who did not know whether there is any relationship between the servant leadership philosophy and PLCEA and other established ideals for Tanzania public leaders.

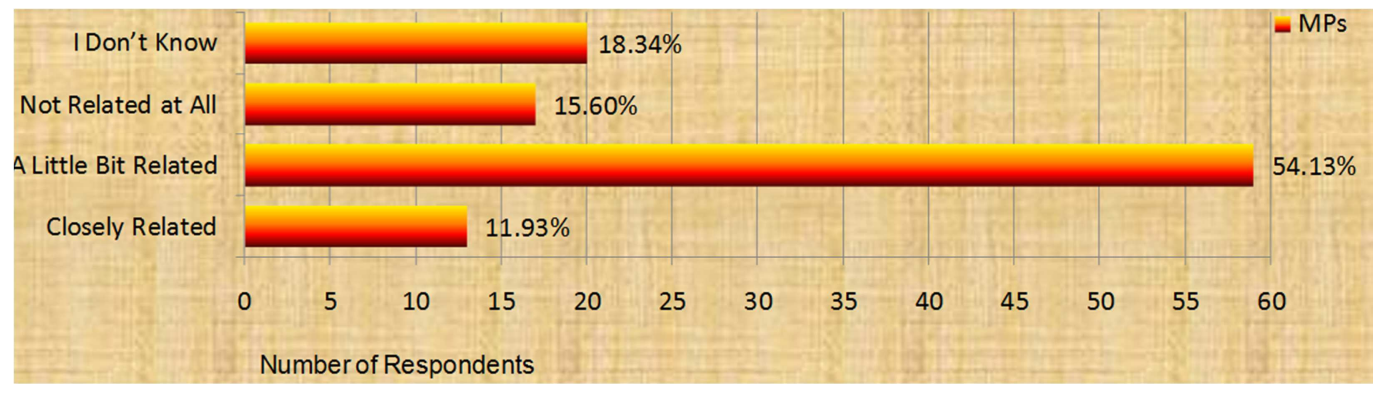

Source: Research Data, 2015

Figure 1. MPS' views on the extent to which SLP relates to PLCEA and other established ideals.

According to the data provided in Table 1 and the analysis made in Figure 1, this category included the second largest cluster of respondents who declared that they did not know about servant leadership philosophy consisting of $20(7.19 \%)$ of the total respondents 278 involved in the study. Therefore, this cluster of $20(7.19 \%)$ were not able to give their opinions to whether the two variables had any relationship. This justifies that the ignorance of SLP was one of the major challenges that prevent public leaders especially MPs from adopting the philosophy of servant leadership. But also these results impliedly suggest that there is a positive correlation between MPs' academic competence and their level of knowledge about the servant leadership philososphy. This study revealed that $38(34.86 \%)$ of MPs involved in this study had academic qualifications of certificate and diploma levels. In that regard, it is true to establish that the problem of ignorance of SLP can be associated to academic competence. Therefore, if Tanzania needs to successfully adopt the servant leadership philosophy, then, one of the major issues to consider and address, among others, is to enhance public leaders' academic competences.

\subsection{RGP' Views}

The 90(100\%) RGPs involved in the study were requested to give their views on the extent to which SLP relates to PLCEA and other established ideals for public leaders. They had to give their opinions using the given four likert-scaled options of 'closely related', 'a little bit related', 'not related at at all' and 'I don't know'. Each respondent was asked to select only one option out of the four given options to express his or her feelings. Table 2 shows responses of all RGPs involved in the study. 
Table 2. RGPS'views on the extent to which SLP relates to PLCEA and other established ideals.

\begin{tabular}{|c|c|c|c|c|c|}
\hline \multirow{3}{*}{ Question: } & \multicolumn{5}{|c|}{ No. of Respondents involved ( $\mathrm{N}=90)$} \\
\hline & \multicolumn{5}{|c|}{ Responses Rating } \\
\hline & $\begin{array}{l}\text { Closely } \\
\text { Related }\end{array}$ & $\begin{array}{l}\text { A Little Bit } \\
\text { Related }\end{array}$ & $\begin{array}{l}\text { Not Related } \\
\text { at All }\end{array}$ & $\begin{array}{l}\text { I Don't } \\
\text { Know }\end{array}$ & Total (\%) \\
\hline $\begin{array}{l}\text { To what extent do you think the principles of servant leadership philosophy } \\
\text { of: increased service to others; holistic approach to work; promoting a sense } \\
\text { of community; and sharing of power in decision-making process relate to } \\
\text { PLCEA and other established ideals for public leaders in Tanzania? }\end{array}$ & $6(6.67 \%)$ & $36(40.00 \%)$ & $19(21.11 \%)$ & $29(32.22 \%)$ & $90(100 \%)$ \\
\hline
\end{tabular}

Source: Research Data, 2015

The data provided in Table 2 reveals that $36(40.00 \%)$ RGPs out of $90(100 \%)$ participated in the study were of the views that SLP was 'a little bit related' to PLCEA and other established ideals for public leaders in Tanzania. However, there was another sub-cluster with a significant number of 29(32.22\%) RGPs who declared that they did not know about the extent to which SLP related to PLCEA and other established ideals for public leaders. The analysis made in Figure 2 shows in detail the distributions of responses given by the RGPs about the extent to which SLP related to PLCEA and other established ideals for public leaders in Tanzania.

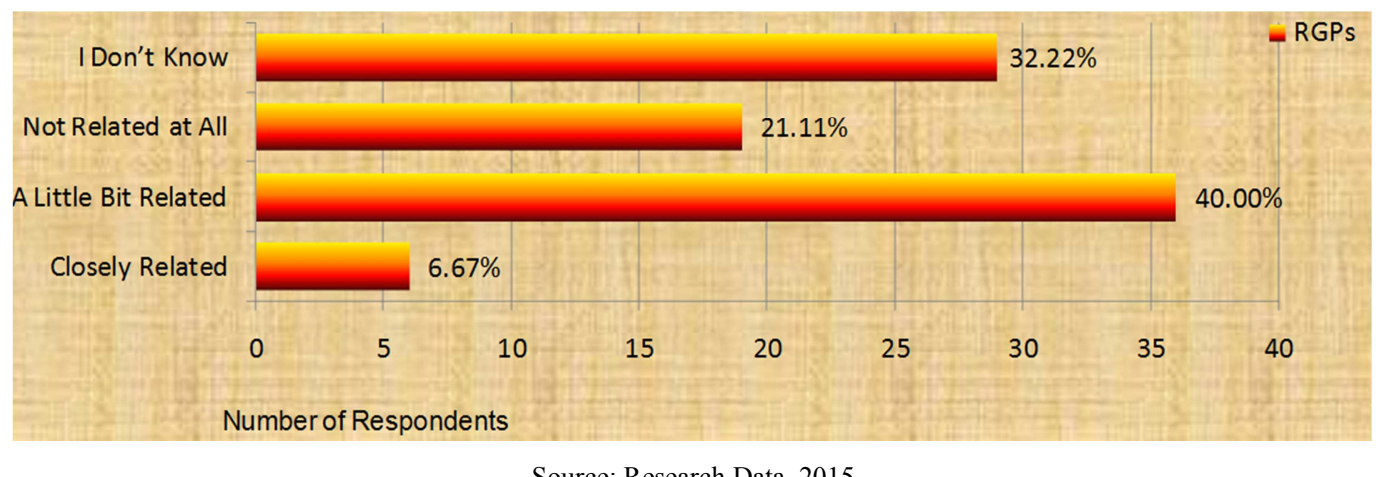

Source: Research Data, 2015

Figure 2. RGPs' views on the extent SLP relates to PLCEA and other established ideals.

The essence of involving RGPs in this study aimed at getting views and opinions from the general public to whether servant leadership philosophy relates to PLCEA and other established ideals for public leaders in Tanzania or not. Basing on the data provided in Table 2 and data analysis made in Figure 2, it can be held that the general public, to a large extent, believed that SLP related a little bit to PLCEA and other established ideals for public leaders in Tanzania where $58(73.42 \%)$ out $90(100 \%)$ RGPs participated in the study had that views. The RGPs category consisted of the largest cluster of respondents who declared to know nothing about SLP. This cluster consisted of 29(32.22\%) out of $90(100 \%)$ RGPs involved in the study equals to $56.86 \%$ of 51 respondents from the three categories who declared to know nothing about servant leadership philosophy. This implies that there is a big number of people from the general public who do not know about SLP especially the illiterate ones. This category was dominated by a group of respondents whose academic qualifications were at certificate and diploma levels consisting of 43(47.78\%) of all RGPs. This proves that the academic competence of RGPs had a greater influence on determining their opinions. Thus, one of the major issues to consider in adopting SLP is about enhancing the literacy level of citizenry.

\subsection{Key Informants' Views}

Seeking to obtain data and views from the involved key informants on the extent to which SLP relates to PLCEA and other established ideals for public leaders, the employed data collection instrument of semi-structured interviews was used. This was the strategic category containing key personalities expected to give important information because of their knowledge related to the study and nature of activities of their institutions. Therefore, the process of interviewing them was purposely done after analyzing the data obtained from the first two clusters of MPs and RGPs in order to cross-check and obtain more clarifications and extra information on some important issues. During the interview their views were carefully recorded and later got analyzed. The analysis revealed that $58(73.42 \%)$ key informants out of $79(100 \%)$ participated in the study were of the views that SLP and PLCEA and other established ideals for public leaders were 'a little bit related'. Only $9(11.39 \%)$ respondents had the views that SLP was 'closely related' to PLCEA and other established ideals. Table 3 shows in detail all responses from key informants as were recorded and analyzed. 
Table 3. Key informants' views on the extent to which SLP relates to PLCEA and other established ideals.

\begin{tabular}{|c|c|c|c|c|c|}
\hline \multirow{3}{*}{ Question: } & \multicolumn{5}{|c|}{ No. of Respondents involved $(\mathrm{N}=79)$} \\
\hline & \multicolumn{5}{|c|}{ Responses Rating } \\
\hline & Closely Related & $\begin{array}{l}\text { A Little Bit } \\
\text { Related }\end{array}$ & $\begin{array}{l}\text { Not Related } \\
\text { at All }\end{array}$ & $\begin{array}{l}\text { I Don't } \\
\text { Know }\end{array}$ & Total (\%) \\
\hline $\begin{array}{l}\text { To what extent do you think the principles of servant leadership philosophy of: } \\
\text { increased service to others; holistic approach to work; promoting a sense of } \\
\text { community; and sharing of power in decision-making process relate to PLCEA } \\
\text { and other established ideals for public leaders in Tanzania? }\end{array}$ & $9(11.39 \%)$ & $58(73.42 \%)$ & $10(12.66 \%)$ & $2(2.53 \%)$ & $79(100 \%)$ \\
\hline
\end{tabular}

Source: Research Data, 2015

The analysis made in Figure 3 shows more details on the distributions of responses given by key informants about the extent to which SLP related to PLCEA and other established ideals for public leaders in Tanzania. Also, it is important to note that this was the most competent category in terms of academic qualifications consisting of 72(91.14\%) respondents whose academic qualifications were above bachelor degree. Only 7(8.86\%) respondents in this category had either certificate or diploma qualifications. On the other hand, this was the leading category with a smallest cluster of respondents declared to know nothing about SLP and the extent to which it related to PLCEA and other established ideals for public leaders consisting of only 2(2.53\%) respondents. Thus, as reflected in the MPs and RGPs categories, this justifies that there is a positive correlation between academic competence of a respondent and his or her level of understanding of the philosophy of servant leadership.

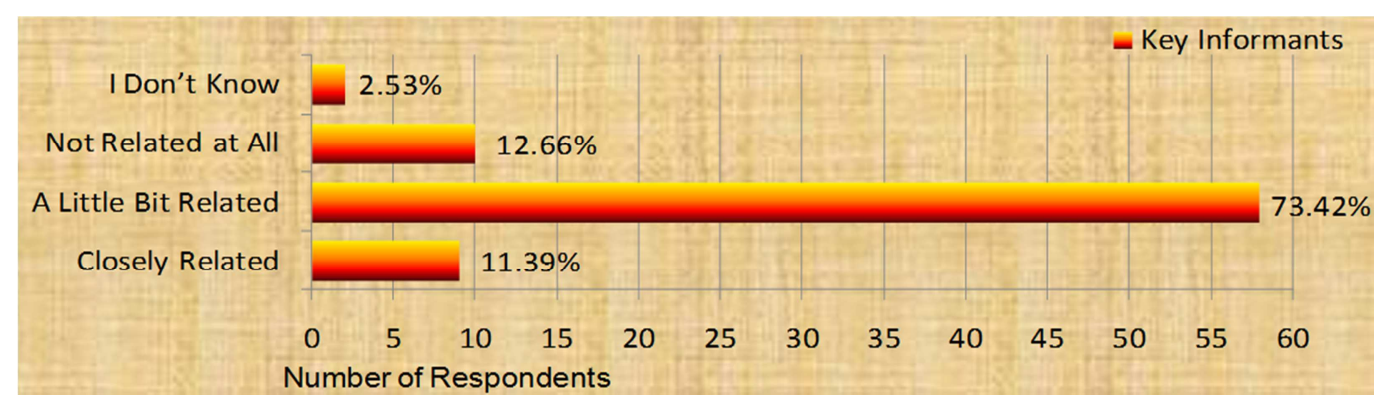

Source: Research Data, 2015

Figure 3. Key informants' views on the extent SLP relates to PLCEA and other established ideals.

Generally, the data collected attempted to examine an extent to which SLP relates to PLCEA and other established ideals for public leaders in Tanzania. The research findings revealed that SLP is a little bit related to PLCEA and other established ideals for public leaders in Tanzania where a total number of $153(55.03 \%)$ respondents out of $278(100 \%)$ involved in the study had that views. On the other hand, the research findings revealed that there was a cluster with a significant number of 51(18.34\%) respondents who declared that they did not know to which extent SLP related to PLCEA and other established ideals for public leaders in Tanzania. Table 4 shows a summary of all responses obtained from the three categories.

Table 4. Summary of views of all respondents on the extent to which SLP relates to PLCEA and other established ideals for public leaders.

\begin{tabular}{|c|c|c|c|c|c|}
\hline \multirow{3}{*}{$\begin{array}{l}\text { Categories of } \\
\text { Respondents Involved }\end{array}$} & \multicolumn{5}{|c|}{ No. of Respondents involved $(\mathrm{N}=\mathbf{2 7 8})$} \\
\hline & \multicolumn{5}{|l|}{ Responses Rating } \\
\hline & Closely Related & A Little Bit Related & Not Related at All & I Don't Know & Total (\%) \\
\hline MPs & $13(4.68 \%)$ & $59(21.22 \%)$ & $17(6.12 \%)$ & $20(7.19 \%)$ & $109(39.20 \%)$ \\
\hline RGPs & $6(2.16 \%)$ & $36(12.95 \%)$ & $19(6.83 \%)$ & $29(10.43 \%)$ & $90(32.38 \%)$ \\
\hline Key informants & $9(3.24 \%)$ & $58(20.86 \%)$ & $10(3.60 \%)$ & $2(0.72 \%)$ & $79(28.42 \%)$ \\
\hline Total & $28(10.08 \%)$ & $153(55.03 \%)$ & $46(16.55 \%)$ & $51(18.34 \%)$ & $278(100 \%)$ \\
\hline
\end{tabular}

Source: Research Data, 2015

In addition, the research findings also revealed that majority of respondents who declared that they did not know to what extent SLP related to PLCEA and other established ideals were coming from the second category of RGPs consisting of $29(10.43 \%)$ respondents followed by respondents from the MPs' category consisting of 20(7.19\%) of all respondents. The last category was that of key informants which had only $2(0.72 \%)$ respondents.
Although the research findings considerably revealed that SLP related a litttle bit to PLCEA and other established ideals, there was a significant group of respondents from the three categories consisting of $46(16.55 \%)$ respondents as shown in Table 4 who had the views that they were 'not related at all'. Inforrmal discussions and semi-structured interviews were conducted to this cluster to explore more information to why they held such opinions. During the 
discussions and interviews, a number of reasons were mentioned and explained. Because of some reasons being repetitively mentioned, a consolidated summary was produced to reflect their ideas and opinions. Table 5 shows a consolidated summary of what revealed to be the differences between SLP and PLCEA and other established ideas.

Table 5. Consolidated summary of differences between SLP and PLCEA and other established ideals for public leaders.

\begin{tabular}{ll}
\hline Servant Leadership Philosophy & PLCEA and Other Established Ideals for Public Leaders in Tanzania \\
\hline $\begin{array}{l}\text { The philosophy seems to be a socialistic based model } \\
\text { with some spiritual characteristics }\end{array}$ & $\begin{array}{l}\text { These are compliance based legislations established to guide public leaders in the public } \\
\text { service. }\end{array}$ \\
$\begin{array}{l}\text { A leader must be a devoted person (a servant) to serve } \\
\text { others in the community. }\end{array}$ & $\begin{array}{l}\text { A leader is any qualified person entrusted with powers to ensure compliance to laws, rules and } \\
\text { Regulations in the community. } \\
\text { A servant-leader is naturally endowed with inner- }\end{array}$ \\
$\begin{array}{l}\text { The commitment of a public leader is subjective depending on how his roles are defined in the } \\
\text { feelings and devotedness of serving others first. }\end{array}$ & $\begin{array}{l}\text { legal framework - what the leader is supposed to do and what he is not. } \\
\text { Emphasis of a servant-leader is on delivery of increased } \\
\text { service to his followers first. }\end{array}$ \\
$\begin{array}{l}\text { Emphasis of a public leader is on compliance of laws, rules and regulations first. } \\
\text { to the same status of a leader. }\end{array}$ \\
$\begin{array}{l}\text { The philosophy inculcates a spirit of patriotism and } \\
\text { holistic approach to work in public leaders. }\end{array}$ \\
$\begin{array}{l}\text { Servant leaders are closer to the people they lead. } \\
\text { Ptatus of the society is a derivative to compliance. }\end{array}$ \\
\hline
\end{tabular}

Source: Research Data, 2015

To conclude, it can generally be established from the data analysis made to the three categories that servant leadership philosophy relates a little bit to current Public Leaders Code of Ethics Act of 1995 and other established ideals for public leaders in Tanzania. Table 4 and Figure 4 show the summary of the research findings that lead to that conclusion. However, the challenge of illiteracy of both the society and some of the public leaders about the servant leadership philosophy acts as a set back to its adoption success in the Tanzania public leadership framework. This is also reflected in the opinions of one of the key informants when requested to give his views to why he thought servant leadership philosophy has not been adopted in the Tanzania public leadership framework while seems to relate a little bit to the current Public Leaders Code of Ethics and other established ideals for public leaders in Tanzania he had the following views:

".... in my personal opinions, it is true that the principles of servant leadership philosophy, a little bit relates to the laid down principles of the existing ethics and code of conduct for public leaders in Tanzania. For they both insist on; service delivery to the public and safeguarding the wide interests of the public against public leaders' individual interests which are the most pleas of the society to their public leaders. However, the illiteracy of both the society and some of the public leaders about the servant leadership philosophy itself acts as a set back to its adoption success and should be the major issue to focus on if we really need to adopt this philosophy in our public leadership framework."

\section{Conclusion and Recommendation}

This research paper examined the extent to which servant leadership philosophy relates to PLCEA and other established ideals. Basing on the research findings it can be concluded that servant leadership philosophy is a little bit related to PLCEA and other established ideals for public leaders in Tanzania. For they both have ethical characteristics intending to set controls over public leaders. A number of differences were established during the study to justify why they were a little bit related. The major difference based on the premises that the philosophy of servant leadership seems to embody socialistic and spiritual characteristics with a major focus on elevating followers to the same status of the leader while PLCEA and other established ideals are mainly based on a legal compliance approach. The other differences mentioned basically focused on personal qualities of a leader in each category.

The research findings of this study have got far-reaching policy implications and impact for the future plans of improving public leadership in Tanzania. It is recommended that policy-makers and other public actors should think of incorporating the principles of servant leadership philosophy in PLCEA and other established ideals in order to have a very strong Public Leaders Code of Ethics Act that restrains public leaders from abusing their powers. Currently, there is no specific comprehensive policy guideline that guides coordination of specific public leadership training for public leaders especially from the political realm rather than efforts made by individual public institutions. This is a major lacuna to the government because as emphasized by Adamson [9] and Northouse [1] the government has the moral obligations and responsibilities of grooming acumen leaders in order to protect life, liberty and property of the people they govern.

The government should therefore think of establishing special institutions for grooming public leaders. This can be possible through the process of reviewing the existing Public Service Training Policy of 2013 with the aim of introducing a special comprehensive leadership programme to be undergone by all newly elected public leaders. The programme should consist of structured strategic leadership issues including; issues of integrity and moral standards, patriotism and servant-leadership philosophy to enlighten them on the dos and don'ts in the public service leadership. The programme, if proper taught, will help, among other things, to mitigate the major problem of conflict of interest and inculcate in public leaders ethical conduct, patriotism 
and a spirit of serving people first rather than looking at their individual interests.

\section{Area for Further Research}

Apart from being a source of reference to politicians, policy-makers and other stakeholders, this study is expected to inspire other academicians and researchers to conduct more related researches. This is because it is the first study to be conducted in Tanzania researching on servant leadership philosophy. It is therefore recommended that more researches have to be conducted with the aim of assessing the general impact and contribution of the servant-leadership philosophy on enhancing integrity, patriotism, ethics and moral standards to both public leaders and other public servants in Tanzania and beyond.

This study is expected to fit much better in the public sector framework rather than the private sector. This is because of its nature and type of data collected. It is therefore further recommended that more researches should be conducted to bridge the existing knowledge gap on whether the SLP has any prospects or not in changing the attitude of both leaders and employees towards their work in the private sector.

\section{References}

[1] Northouse, P. G. (2013). Leadership: Theory and practice. 6th Ed. Singapore: Sage Publications, Inc.

[2] Greenleaf, R. K. (2002). Servant-leadership: A journey into the nature of legitimate power and greatness. Mahwah, NJ: Paulist Press.

[3] McGee-Cooper, A. and Trammell, D. (2013). The Essentials of Servant Leadership: Principles in Practice. Dallas: Texas.

[4] Weinstein, R. B. (2013). Servant leadership and public administration: Solving the public sector financial problems through service. Journal of Management Policy Practices. 14, 84-92.

[5] Jennifer, M. (2012). Why should I Vote?: Democracy at a secondary level. MSM Productions Ltd.

[6] Gasarasi, C. (2004)."The General Environment in which the Members of Parliament Work" In Mukandala, R. S. et. al (ed). People's Representatives: Theory and Practice of Parliamentary Democracy in Tanzania. Fountain Publishers Ltd. Kampala.

[7] Liviga, A. (2004)."The Role of Members of Parliament as Representatitives of the People". In Mukandala, R. S. et al (ed). People's Representatives: Theory and Practice of Parliamentary Democracy in Tanzania. Fountain Publishers Ltd. Kampala.

[8] URT. (1995). The Public Leadership Code of Ethics Act No.13 of 1995. Dar es Salaam: Government Printer.

[9] Adamson, K. A. (2012). The Ecology of Leadership: Examining the Relational Dynamics of Dyads. School of Global Leadership and Entrepreneurship Regent University.
[10] Mole, G. (2004) 'Can Leadership Be Taught?', in Storey, J. (2004) Leadership in Organizations: Current Issues and Key Trends. New York: Routledge, pp. 125-137.

[11] Winkler, J. (2010). Contemporary leadership theories: Enhancing the understanding of the complexity, subjectivity and dynamic of leadership. London: Springer.

[12] Van Wart, M. (2012). Leadership in public organisations: An introduction. 2nd Ed. Florida: M. E Sharp Inc.

[13] Bass, B. M. and Stogdill, R. M. (1990). Handbook of Leadership Theory, Research and Managerial Applications. New York: Simon and Schuster Publishing.

[14] Oxford English Dictionary. (1971). Oxford University Press.

[15] Sendjaya, S. and Cooper, B. (2011). Servant leadership behaviour scale: A hierarchical model and test of construct validity. Eur. J. Work Organ. Psychol. 20, 416-436.

[16] The New International Version Bible. (1986). Concordia SelfStudy Bible. St. Louis, MO: Concordia Publishing.

[17] Ruona, W. and Lynham, S. (2004). Towards a philosophical framework for thought and practice. Human Resource Development International, 7(2), 151-164.

[18] Savage-Austin, A. R. and Honeycutt, A., (2011). Servant leadership: A phenomenological study of practices, experiences, organizational effectiveness, and barriers. Journal of Business and Economics Research (JBER), 9(1).

[19] Jaiswal, N. K., Dhar, R. L. and Dhar, R. L. (2017). The influence of servant leadership, trust in leader and thriving on employee creativity. Leadership and Organization Development Journal, 38(1), pp.2-21.

[20] Greenleaf, R. K., (2002). Servant leadership: A journey into the nature of legitimate power and greatness. Paulist Press.

[21] Spears, L. C. (2004). Practicing servant leadership. Leader to Leader, 34(1) 7-11.

[22] Carroll, B. C. and Patterson, K. (2014). Servant leadership: A cross cultural study between India and the United States. Servant Leadership: Theory and Practice, 1(1), pp.16-45.

[23] Cooper, S. S. (2010). Servant Leadership Behaviour Scale: A hierarchical model and test of. European Journal of Work and Organizational Psychology.

[24] Laub, J. (2004). Defining Servant Leadership: A Recommended Typology for Servant Leadership Studies. Proceedings of the 2004 Servant Leadership Research Roundtable.http://www.regent.edu/acad/global/publications/sl proceedings/home.shtml.

[25] Spears, L., ed. (2002). Focus on leadership: servantleadership for the 21st century. New York: John Wiley and Sons Inc.

[26] Nyerere, J. K. (1968). Freedom and Socialism. Oxford University Press: Tanzania.

[27] Nyerere, J. K. (1995). Our Leadership and the Destiny of Tanzania. African Publishing Group: Harare.

[28] Othuman, H. (ed), (2000). Reflections on Leadership in Africa Forty Years after Independence. University of Dar es Salaam and VUB University press: Belgium. 
[29] Chachage, S. L. (2000). University of Dar es Salaam Newsletter 1999/2000. University of Dar es Salaam Press: Tanzania.

[30] Haussler, P. (2009). Leadership for Democratic Development in Tanzania: The Perspective of Mwalimu Julius K. Nyerere During the First Decade of Independence: Dar es Salaam.

[31] United Nations (2013). World Bank Report. Retrieved from: worldbank.org/report2013 on 20.05.2015.

[32] Tenga, R. W. (2010). The Legal Framework for the Regulation of Public Ethics in Tanzania: A Paper Presented to the Workshop for Members of Parliament of the United Republic of Tanzania Organized by The Ethics Secretariat: April, 27.

[33] The Citizen News Paper, (2013). Leadership Vacuum Hurts the Nation: Elders: Saturday, July, 27: P.4.

[34] Ngowi, H. P. (2007). Economic Development and Change in Tanzania since Independence: The Political Leadership Factor. A Paper Presented at $29^{\text {th }}$ AAPAM Annual Roundtable Conference: Mbabane, Swaziland.

[35] The Citizen News Paper, (2015). Kikwete: No Development without Ethical Public Leaders: Tuesday, April, 14: P.3.

[36] Nassor, S. H. (2007). Developing the Tanzania Public Service Leadership Competency Framework. A Paper Presented at
Leadership, Learning, Institutes and Public Service Conference: Accra, Ghana.

[37] Kothari, C. R. (2004). Research Methodology: Methods and Techniques, $2^{\text {nd }}$ Edition. India.

[38] Bryman A (ed.). 2011. Research Methods in the Study of Leadership. Sage: London.

[39] Creswell, J. W. (2009). Research Design: Qualitative, Quantitative and Mixed Methods Aproaches: Sage Publications. London.

[40] Sekaran, U. (2003). Research Methods for Business, A Skill Building Approach. $4^{\text {th }}$ Edition, New Jersey: Haboken Publishers.

[41] Awino, Z. B. (2007). The Effect of Selected Variables on Corporate Performance: A Survey of Supply Chain Management in Large Private Manufacturing Firms in Kenya. Unpublished Thesis report, University of Nairobi.

[42] Abok, A. M. (2013). Factors Affecting Effective Implementation of Strategic Plans in Non-Governmental Organizations in Kenya, JKUAT-Nairobi: unpublished report.

[43] Mugenda, O. M., and Mugenda, A. G. (2003). Research Methods: Quantitative and Qualitative Approaches. Nairobi: Acts Press. 